 \\ IJCTA Indonesian Journal of Tropical Aquatic
}

\section{Masculinization of Rainbow Fish (Melanotaenia boesemani) through immersion the larvae with extract of bee honey resin as a natural substance with different doses}

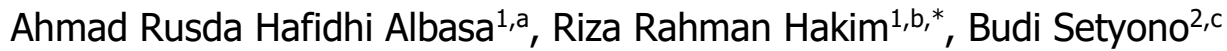 \\ ${ }^{1}$ Fisheries Department, Faculty of Agriculture and Animal Science, University of Muhammadiyah \\ Malang, Indonesia. \\ ${ }^{2}$ Marine and Fisheries Department of East Java Province \\ arusdahafidhi@gmail.combrizahman@umm.ac.id cbudisetyono@gmail.com \\ ${ }^{*}$ Corresponding author
}

\section{ARTICLE INFO}

Keywords:

Rainbow fish

Melanotaenia boesemani

Masculization

Extract propolis
ABSTRACT

The development of exports ornamental fish gives the production ornamental fish in Indonesia incredibly global including the Rainbowfish (Melanotaenia boesemani) having a different economic value where male fish have an economic value higher than the female. Productivity male mono-sex can be done by the masculinization method by the use of natural resin honeybees. Methods used to research this is the Complete Randomized Sampling method with 4 treatments $(0.5 \mathrm{ppm}, 1 \mathrm{ppm}, 1.5 \mathrm{ppm}, 2 \mathrm{ppm})$ and 4 repetitions. Data analyzed using analysis ANOVA. The results showed that Bee resin (Propolis) can improve the effect of masculinization from a Rainbowfish with average to the percentage a kind of male on $0.5 \mathrm{ppm}$ to $2 \mathrm{ppm}$ treatment is $43.92 \%$, $62.74 \%, 50.28 \%$, and $59.49 \%$. While treatment and control areas as much as $52.80 \%$. Based on the results of the study, it can be concluded that masculinization of Rainbow Boesemani fish ( $M$. boesemanI) by soaking the larvae using honey Bee resin (propolis) with different doses give effect to the masculine effect of Rainbowfish is best at a dose of $1 \mathrm{ppm}$ with a procession of $62.74 \%$

How to cite:

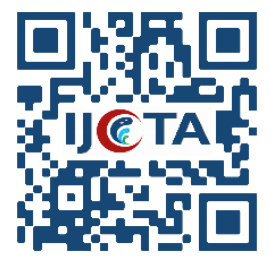

Albasa ARH, Hakim RR, Setyono B. 2019. Masculinization of Rainbow fish (Melanotaenia boesemani) through immersion the larvae with extract of bee honey resin as a natural substance with different doses. IJOTA, 2(1): 33-39. DOI: https://dx.doi.org/10.22219/ijota.v2i1.6047

Copyright (c) 2019, Albasa et al. This is an open access article under the CC-BY-SA license

\section{Introduction}

Aquaculture is a form of maintenance and breeding various kinds of animals or plant waters that uses water as a live media. One of the cultivation that could be performed and developed was the cultivation of ornamental fish. It has good potency in the market, local, and global markets. The ministry of marine and fisheries explained that Indonesia is placed third producer of ornamental fish 
after china and Singapore with potential the export value trading reached us $\$ 65$ million (KKP, 2016). The development of ornamental fish export, which rapidly on each year offers the potential for ornamental fish the production of Indonesia to a global market. According to Said (2003) ornamental fish, the profits from the sale of export commodities were increasing every year $20 \%$, especially for the undetectable fish, which is endemic. One of the products of ornamental fish endemic Indonesia was a fish boesemani rainbow ( $M$. Boesemani) within the ranks of what they were in the category of ornamental fish have the potential to export. M. boesemani, the rainbow fish, is a native fish endemic derived from Papua. This fish for its beauty and uniquely had much cache. Besides, this fish also accessible to the care of media at that maintenance as in a pool of land, concrete tube, and aquarium.

As ornamental fish in general, M.boesemani having a distinct physical between males and females. According to Billard (2012), distinction male and female at an M. Boesemani is having a brighter, dorsal both longer up to the tail fin and his size larger at a male fish, and on the females have anatomy on the stomach larger, and dorsal both shorter than a male fish. Hence if seen from an economic aspect, $M$. boesemanimale has the economic value that higher. This is because of the physical features of $M$. boesemani male more attractive and market in higher demand.

Vigorous monosex productivity can increase the amount of $M$. boesemani in the economic aspect. The conclusion can be achieved by doing a masculinize method. But to the process masculinize in general still use chemical substances that can give rise to the residue that dangerous either on the biota, ecosystem, environment, and it does to a man. Hence is required a make a breakthrough in the methods of masculinizing for producing monosex male on M. boesemani safely and does not cause a residue. The use of materials stimulators and inhibitors of hormone that is natural safer and environmentally friendly than with synthetic material that could leave a residue poisonous in waters and an organism waters (Contrerass. et al. 2000). One of the natural materials that can be used in the methods of masculinizing for producing monosex resin from the bulls is of a bee or more in familiar with propolis appellation. This report aimed to understand appropriate doses for the production of male monosex at an M. boesemani using of natural propolis is expected to reduce the number of residue pra-treatment. Treatment is dipping will be used for the larvae newly hatched find softness doses uniform size.

\section{Material and methods}

\subsection{Procurement stem.}

M. boesemani was obtained from the Pamulang, South Tangerang, with size an average of $5 \mathrm{~cm}$. The fish are kept in aquariums with capacity $110 \times 50 \times 50 \mathrm{~cm}^{3}$ for mating. The 100 of fish was acclimated with ration 30 male: 70 female.

\subsection{Matting stem.}

The aquarium placed on sized $50 \times 30 \times 30 \mathrm{~cm}^{3}$ and shelves aquariums prepared the maintenance, then stem put into a barrel by comparison male-female 2:1, the substrate a starter rope raffia put into an aquarium spawning in the afternoon and lift in the morning. The substrate was moved to an incubator to the process of hatching. 


\subsection{The manufacture of resinous extract honeybees}

Weigh the bee resin honey for $1 \mathrm{gr}$, measure $20 \mathrm{ml}$ of sterile water and heated on a hotplate, including propolis into water heat, sift extract with a paper filter, inserting extract into falcon tube to a process of storage.

\subsection{Treatment and maintenance of larvae}

Larva has hatched and was 4 days be soaking extract treatment, using every procedure 30 larvae and immediately put into plastic sized 5 pounds who has water 1 liter and dosage extract bee resin appropriate treatment. Treatment is given 30 larvae without being treatment soaking extract bee resin for 12 hours. The 30 larvae were soaked to propolis $0.5,1,1.5$, and 2 ppm for 12 hours per each. Larvae who have received treatment then be oxygen and tied meeting. After 12 hours, larvae are moved to the tending to care for 28 days. Larvae who have been given treatment then maintained up to the age of 28 days. The rotifer was given for 3 to 15 days of cultivation, while the larvae artemia was for aged 15 to 28 days. Every seven days, clean of waste was conducted to clean water media. The larvae have $\mathbf{2 8}$ days or more in age observed the sexuality to see male or female.

\subsection{Identification of gonads}

Larva was identified kind of gonads. The larvae was cut the head and their tails that left the their bodies, and torn put on an object-glass, then given asetokarmin using disposable as many as one drops to sample, and covered with cover glass and pressing with a view to parts of the body the fish readily observable, then wait for two till 3 minutes, then observed under a microscope with of magnitude 40-1000 times.

\subsection{Calculation percentage male organs}

Main parameters found in the research was the percentage of male organs at $M$ boesemani result of soaking using extract bee resin (Propolis) with the formula calculations:

$$
\alpha=\frac{\text { Male larvae }}{\text { Larvae total }} \times 100 \%
$$

\subsection{Data Analysis.}

All data from every treatment were analyzed statistically using analysis of variance (ANOVA) based on the random design complete at the trust $95 \%(\alpha=0,05)$ and $99 \%(\alpha=0,01)$. When the variety of data fingerprint note that treatment show an influence real or different very real (f.count \& gt; $f$ table ) hence to tell the difference between four treatment followed by the smallest different real.

\section{Results and Discussion}

\subsection{Gonad identification.}

Gonad identification was performed using asetokarmin solution as a supporting. The primary function of asetokarmin was as a dye. The result of observations was presented in Figure 1. 

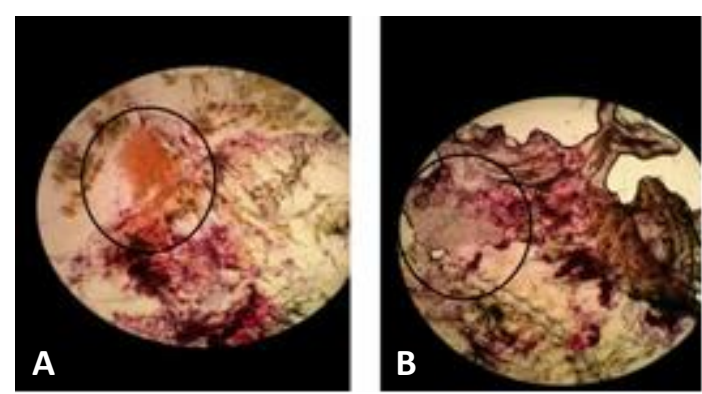

Figure 1. (A) Sperm, (B) Ovary

Figure 1 showed the difference between male and female gonads of M. boesemani. On gonads male (Fig. $1 \mathrm{~A}$ ) were characterized by the presence of bubble very small and smooth and usually colored yellowish identified as the head of sperm, and the female gonads (Fig. 1B) characterized by the presence of bubble white clear slightly hollow with small identified as the egg nucleus in the middle. In determining the sex fish or gonads, M. boesemani can be done by staining asetokarmin. The larvae cut on the tail and his head and placed on object-glass, then a drop dye asetokarmin one drop and covered by using cover glass. Prospective gonad that has been colored then observed using a microscope with of magnitude 40x (Soelistyowati et al., 2007).

\subsection{Male percentage.}

Parameters of research was the male percentage that could come from soaking larvae for 12 hours with different doses using resinous extract honeybees (Propolis). For every treatment given, values on the effects masculine posed. The result of soaking fish larvae rainbow (M. boesemani) with resin propolis to effect masculinize seen in Table 1:

Table 1. Average male presentation

\begin{tabular}{cccccc}
\hline \multirow{2}{*}{ Treatment } & \multicolumn{3}{c}{ Repetition } & Total & $\begin{array}{c}\text { Average } \\
(\%)\end{array}$ \\
\cline { 2 - 4 } & 1 & 2 & 3 & & 43.92 \\
A & 50.00 & 38.89 & 42.86 & 131.75 & 43.74 \\
B & 61.54 & 60.00 & 66.67 & 188.21 & 62.74 \\
C & 58.33 & 62.50 & 60.00 & 180.83 & 60.28 \\
D & 58.82 & 62.50 & 57.14 & 178.47 & 59.49 \\
\hline
\end{tabular}

The effect masculinize increased when given a dose resinous extract honeybees as many as 1 ppm. It supported data on other treatments which showed more doses given do not guarantee a higher result. From soaking fish larvae rainbow boesemani with a dose of $1 \mathrm{ppm}$ with a long time $12 \mathrm{~h}$ provide the best results against the effects of masculinity. These are similar to previous studies done by Sarida et al. (2011) that produces the percentage of the male population is relatively high on treatment soaking larvae betta fish of $67,13 \%$ with $1 \mathrm{ppm}$ doses. Effect masculinize greater 1 ppm doses can happen because the resinous extract honeybees can provide levels of aromatase inhibitor that is precisely so slow even hinder the performance of fish in secreting enzyme aromatase that is a catalyst in the formation of gonads female. This is supported by the opinion of Woo (2004) stating that inhibitor aromatase is a barrier of enzymatic reactions aromatase and biosynthesis estrogen, as a result, only will appear to masculinize effect. Besides Piferrer et al. (1994) in Lee et al. (2003) said that on fish inhibition against the activity of the aromatase physically (temperature) and chemistry (fradozole, imidazole) causing effects masculinize equal to posed by androgen on 
several species. When connected with this research, there is a correlation and caused the activity enzyme aromatase occurring in the body fish larvae to object hampered by the treatment provided by the use of extract propolis.

\subsection{Survival rate.}

In addition to the potent effect, this study had another primary parameter. It was the survival rate of $M$. boesemani. For this study, the survival rate was obtained from the number of larvae at the beginning of the treatment compared with the number of fish at the end of treatment. Based on this study, the level of survival was calculated to know the treatment by giving honey bee extract (Propolis) with different doses given significantly or not to the survival rate of $M$. boesemani fish larvae for 28 days starting. The survival rate or survival rate of $M$. boesemani fish in each treatment can be seen in Table 2.

Table 2. Average of survival rate of $M$. boesemani larvae:

\begin{tabular}{cccccc}
\hline \multirow{2}{*}{ Treatment } & \multicolumn{3}{c}{ Repetition } & Total & \multirow{2}{*}{ Average \% } \\
\cline { 2 - 4 } & 1 & 2 & 3 & & 57.78 \\
A & 66.67 & 60.00 & 46.67 & 173.33 & 44.44 \\
B & 43.33 & 50.00 & 40.00 & 133.33 & 44.44 \\
C & 40.00 & 26.67 & 66.67 & 133.33 & 35.56 \\
D & 56.67 & 26.67 & 23.33 & 106.67 & \\
& Total & & & 546.57 & \\
\hline
\end{tabular}

Table 2 showed that the highest average survival rate was in treatment $A$, where treatment $A$ had a mean value of $57.78 \%$ survival and control treatment had a mean value of $57.78 \%$. While $B$ and $C$ treatment had the average value of the same survival of $44.44 \%$. The average of the lowest survival rate was in treatment $D$ with an average value of $35.56 \%$. Low survival rates on treatment $D$ due to too much resin bee extract was given so that it might affect the normal activity of the body's metabolism of objects. It also could ultimately lead to death on the purpose. Besides, the low level of life sustainability was caused by the content in propolis that is not following the needs and tolerances of the material.

\subsection{Growth rate larvae.}

Growth rate was obtained by comparing the weight of fish at the beginning and the end of the treatment using a digital scale. The growth rate in grams in this study could be seen in Table 3.

Tabel 3. Average growth rate larvae Rainbow Boesemani Fish (M. boesemani)

\begin{tabular}{cccccc}
\hline \multirow{2}{*}{ Treatment } & \multicolumn{3}{c}{ Repetition } & Total $(\mathrm{g})$ & Average $(\mathrm{g})$ \\
\cline { 2 - 4 } & 1 & 2 & 3 & & \\
\hline A & 0.0195 & 0.0211 & 0.0203 & 0.0609 & 0.0203 \\
B & 0.0217 & 0.0211 & 0.0197 & 0.0625 & 0.0208 \\
C & 0.0194 & 0.0236 & 0.0216 & 0.0646 & 0.0215 \\
D & 0.0211 & 0.0207 & 0.0193 & 0.0611 & 0.0204 \\
& & & & 0.2491 & \\
\hline
\end{tabular}

The average of fish growth each treatment comes in A $(0.5 \mathrm{ppm})$ with 0.0203 , for treatment B (1 ppm) of $0.0208 \mathrm{~g}$, treatment C (1.5 ppm) of $0.0215 \mathrm{~g}$, and treatment D (2 ppm) with 0.0204 $\mathrm{g}$. Based on it, each treatment had a relatively similar rate of growth. Those could happen because 
the maintenance containers have been set such as the environmental conditions not differ from one to another. This is supported by Agus et al. (2010) which states, internal and external factors influence the growth of fish. Internal factors include gender and genetics. While for an external factor that is feed and environment which include temperature, dissolved oxygen and $\mathrm{pH}$. Besides, the number of fish during maintenance.

\subsection{Water quality.}

Water quality is an essential factor in conducting cultivation activities because water quality such as temperature, $\mathrm{pH}$ and dissolved oxygen can affect the metabolic processes in the body of aquatic organisms. The measurement of water quality was recorded at 15:00 and 07:00 pm. From dissolved oxygen or DO data in the morning ranged from 5.38 to $8.43 \mathrm{ppm}$, and during the day ranged from 5.12 to $7.87 \mathrm{ppm}$. According to Nasution (2000), the best-dissolved oxygen (DO) for the growth of Rainbow Boesemani (M. Boesemani) fish larvae was $>4 \mathrm{mg} / \mathrm{l}$. For the values of $\mathrm{pH}$ measurements, it can be seen that the difference between $\mathrm{pH}$ in the morning and noon was not particularly susceptible to different values, i.e. $\mathrm{pH}$ in the morning ranges from 6.5 to 7.8 and during the day varies from 6.1 to 7.3. According to Nasution (2000), the $\mathrm{pH}$ is recommendable for fish larvae ranging from 6 to 8 but the $\mathrm{pH}$ was preferably slightly alkaline (above 7). The $\mathrm{pH}$ value was too low in the acidic state causing the appetite of fish to decrease and can affect the poison for the survival of the fish. The above water quality range results are within reasonable tolerable limits to support the growth of Rainbow Boesemani fish larvae

\section{Conclusion.}

Based on the result of the research, it can be concluded that the application of bee resin (Propolis) for soaking Rainbow Boesemani fish larvae could produce masculinization effect of 43.92 $\%$ at treatment $A(0.5 \mathrm{ppm}), 62.74 \%$ at treatment $B(1 \mathrm{ppm}), 60.28 \%$ in treatment $C(1.5 \mathrm{ppm})$, and $59.49 \%$ in treatment $D(2 \mathrm{ppm})$, and the best dose was found in treatment $B(1 \mathrm{ppm})$ males of $62.74 \%$ of the total population.

\section{References}

Agus M, Yusufi M, Nafi B. 2010. Pengaruh perbedaan jenis pakan alami daphnia, jentik nyamuk dan cacing sutera terhadap pertumbuhan ikan cupang hias (Betta splendens). Pena Akuatika. 2(1): 21-29

Billard R. 2012 . Reproduction in rainbow trout,dinamic of gametogenesis, biology and preservation of gametes. Aquaculture. 100: 263-298.

Contreras-San'nchez WM, Fitzpatrick MS, Schreck CB. 2000. Masculinization of nile tilapia by immersion in trenbolone acetate. World Aquaculture Society, New Orleans, LA, p. 65

KKP (Kementerian Kelautan dan Perikanan). 2016. Mendongkrak-Devisa Negara - Melalui- EksporIkan Hias. http://www.kkp.go.id/ik anhias/index.php/news/c/47/ diakeses pada 28 Februari 2018

Lee YC, Chou LB, Han CM. 2003. Reproduction performance of Melanotaenia boesemaniunder stress condition in resirculation ponds. Journal Research Aquaculture. 16(4): 120-127.

Nasution SH. 2000. Ikan Hias Air Tawar Rainbow. Penebar Swadaya. Jakarta. 96 hlm.

Said. 2003. Jantan dengan Perendaman Induk Bunting dan Larva dalam Propolis Berbagai Aras Dosis. Jurusan Budidaya Perairan, Fakultas Pertanian. Universitas Lampung, Bandar Lampung 
Sarida A, Putra D, Marsewi. 2011. Produksi Monoseks Guppy (Poecilia reticulata) menggunakan teknik sex-reversal. Jurnal Akuakultur Indonesia. 18(2): 42-49.

Soelistyowati DT, Martati E, Arfah H. 2007. Efficacy of honey on sex reversal of Guppy (Poecilia reticulata Peters). Jurnal Akuakultur Indonesia. 6(2): 155-160.

Woo K. 2004. Use of bee venom and propolis for apitherapi in Korea. Di Dalam Proceeding of 7th Asian Apicultural Associato Conference and 10th BEE) ET Symposium and Technofora; Los Banos, Februari 2004. Los Banos: Univ Phillipines. pp: 311-315. 